\title{
A TRIBUTE FROM THE TROPICAL MEDICINE INSTITUTE OF SÃO PAULO IN MEMORY OF LEÔNIDAS DE MELLO DEANE AND HIS WIFE MARIA JOSÉ VON PAUMGARTTEN DEANE
}

\author{
Prof. Carlos da Silva LACAZ
}

Like Francisco de Castro, the "divine wizard", put it, every now and then the dead should momentarily awaken from the quietness of their tombs so that their future generations could depose the suffrage of their cult.

The majority of human individuals see life go by without being noticed. They were useless to their kins, to society and to the nation in which they were born. Yet others have taken power to carry out the dreadful genocides that history has recorded. One can recall the example of crimes committed by the Nazi and the communists, which are heterozygous twins of unsuccessful and defeated political systems which show no respect for human freedom and dignity whatsoever.

Nevertheless, amidst this barbarism some Homo sapiens are distinguished and they deserve the respect, appreciation and admiration from their kins, for having done good, having served mankind and done everything to the glory of the Almighty. In the silence of their labs, having no boast whatsoever, they performed notable research work, bearing in mind the well-being of mankind. In this article, as an old Director at IMTSP, where in the past Leônidas de Mello Deane and Maria José von Paumgartten Deane worked, I set forth the high human attributes and scientific value of both the eminent colleagues who vanished into the space-time continuum, leaving relevant services rendered to science and humanity.

In order to write about the life and work of Leônidas and Maria Deane, I avail myself of the excellent biography that Prof. José Rodrigues Coura, current Director for Instituto Oswaldo Cruz, wrote to honor those two reputable colleagues, which biography was presented in a cultural session that took place at the Evandro Chagas Institute (Belém, Pará) on November 10, 1996 upon the $60^{\text {th }}$ anniversary of the said Institute.

Leônidas de Mello Deane was born in Belém (Pará) on March 18,1914 , son of a British man from Barbados, Leonard Eustace Deane, who was an accountant at firm named "Amazon River", which thereafter became "Port of Pará", and later on was nationalized as "Amazon Shipping and Port Administration Service". Having arrived at Belém, he married Helvécia de Mello, who was from Pará state. The couple had four children: Leônidas, Gladstone, Dolly (the only girl) and Percy, the youngest of the boys.

Maria José, born July 16, 1916 in the state of Pará, was the eldest child of Sigmund von Paumgartten, of Austrian and Italian extraction, and of Adelaide Borges, from a Portuguese family. Besides Maria José, also born were Luiza, Amalia, Lídia and Francisco, the youngest and only boy of the family.

In 1930 Leônidas Deane entered the former Medicine and Surgery Faculty of Pará, graduating in Medicine in 1935. Maria, two years younger, graduated in 1937 as an outstanding student.

Upon completion of his medical course, Leônidas Deane conquered the Raul Leite prize for having ranked first in all the medical course series. Lobato Paraense, a renowned Brazilian parasitologist, a mate of Leônidas Deane's group, attests that in those days Leônidas could draw the parasites he studied in color.

As a great cartoonist, he published caricatures about some professors in the "O Acadêmico de Medicina" ("The Medicine Academic") journal. He also described a hemoproteus in the rainbow boa's erythrocytes.

At that time, Leônidas wrote a free text directed to his classmates on $\mathrm{pH}$, didactically explaining the electrolytic dissociation theory and its laboratory use.

According to Prof. José Rodrigues Coura, the couple Leônidas and Maria Deane underwent three great doctrinal influences while students of Medicine and at the start of their careers, namely: from Prof. Aben Athar, a disciple of Oswaldo Cruz, from Antonio Acatauassu Neves, a Microbiology professor and the introducer of Clinical Pathology in Pará state and from Evandro Chagas, a renowned tropicalist, son of the late Prof. Carlos Chagas. In Belém, he created an Institute of Experimental Pathology for the North (1931), nowadays the Evandro Chagas Institute. Evandro Chagas was surrounded with the great talent of Leônidas and his brother Gladstone, together with Felipe Nery Guimarães, Octávio Magalhães Filho, Benedicto de Abreu Sá and Maria Deane. They were all very young. Evandro Chagas was 32, Leônidas 22 and Maria 20 when they started in Caxambú (1986) what Maria Deane named "the great epic".

From 1936 to 1939, Leônidas and Maria worked in Amazonia, being later relocated to the Northeast, in order to combat the Anopheles gambiae, the malaria transmitter.

On October 24, 1940, Leônidas and Maria married and thus, together they mutually increased their scientific potential. 
LACAZ, C. da S. - A tribute from Tropical Medicine Institute of São Paulo in memory of Leônidas de Mello Deane and his wife Maria José von Paumgartten Deane. Rev. Inst. Med. trop. S. Paulo, 40 (4): 267-268, 1998.

In 1944-1945, after taking courses in Entomology and Human Parasitology at the Michigan University, the Deanes achieved the "Master of Public Health" degree from the John Hopkins University, the most famous Public Health School of the world. They were already well known as researchers, when they took a course in Entomology Techniques with Prof. Garham, a fraternal friend of the Deane couple.

In 1953, Prof. Samuel Barnsley Pessoa, my paranymph (1940 Graduates), the late master and Professor of Parasitology for the Medicine Faculty of the USP (University of São Paulo) invited Leônidas and Maria Deane to become his assistants. At the Tropical Medicine Institute, Maria Deane worked until 1992.

The couple was awarded the Oswaldo Cruz (1955) prize by the Medicine Academy of São Paulo and the Ciba prize of Tropical Medicine, the latter in collaboration with Victor Nussenzweig and Judith Koetzel, for the study on antigenic differences among strains of Trypanosoma cruzi.

In 1970, Leônidas Deane was also received as a visiting scientist at the Imperial College in England. He lectured at the Federal University of Minas Gerais and in Lisbon from 1975 to 1976, and also at Carabobo University in Valencia, Venezuela.

At the end of their victorious scientific career, the Deane couple was invited by Prof. José Rodrigues Coura to work for the Oswaldo
Cruz Institute. In 1986, Leônidas Deane received the Moinho Santista prize and in 1990 the Third World Academy of Sciences prize, for basic sciences, also conferred to the Deane couple, in 1991.

Prof. Coura rightly stressed that Leônidas and Maria lived together for about 60 years. Although of different temperaments, they were almost hand-in-glove.

In 1987, the Federal University of Pará conferred upon the Leônidas and Maria Deane couple the honorable degree of Professor Honoris Causa. The Deane couple had a daughter, Luisa Deane.

I had the privilege of having met and being very closely acquainted with these illustrious colleagues, giving them all support at the Tropical Medicine Institute of São Paulo.

Malaria, leishmaniasis and the American trypanosomiasis were the preferred themes of these two Brazilian highly educated parasitologists, both internationally renowned.

Through their Journal, the Tropical Medicine Institute of São Paulo wishes to pay the most fair tribute to the two Brazilian citizens that have contributed so much to the progress of Brazil.

As dignifying examples of work and nobility, they have well deserved this acclaim from the nation. Thus, we honor, these eminent Brazilian researchers.

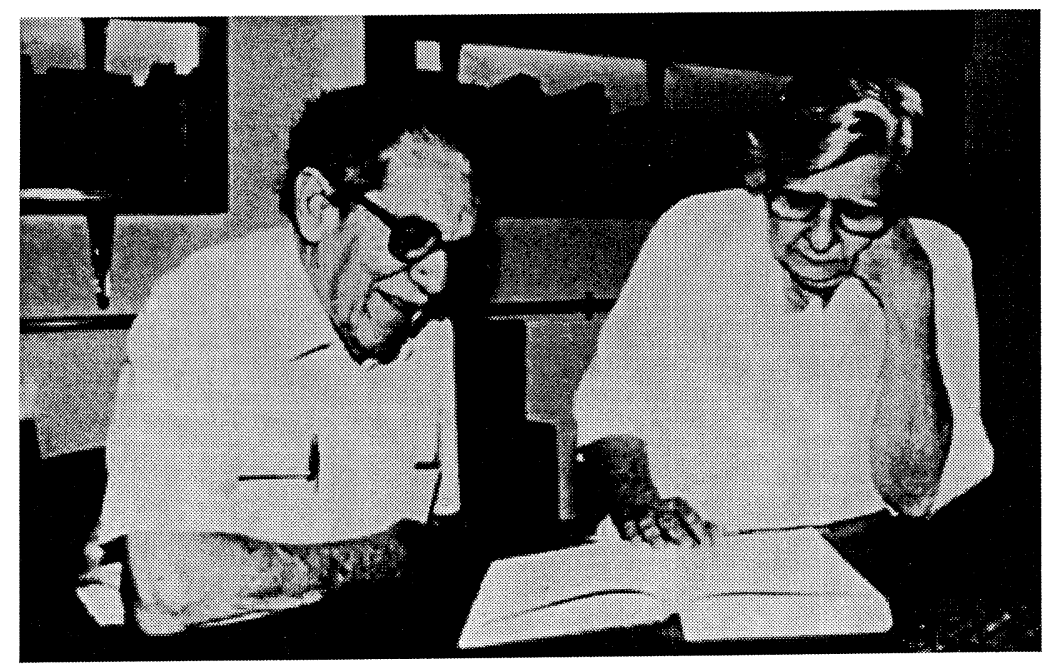

Leônidas de Mello Deane (Mar. 18, 1914 - Jan. 31, 1993) and Maria José von Paumgartten Deane (July 16, 1916 - Aug. 13, 1995), eminent Brazilian parasitologists, were both born in Belém, state of Pará. They worked at the Tropical Medicine Institute of São Paulo, during its early days, having conquered the Third World Academy of Science award in 1991. They published many papers, thus contributing to a better understanding of malaria, leishmaniasis and American trypanosomiasis. They deserve the respect and admiration from all their colleagues. 